\title{
PENGARUH TEKNIK KLARIFIKASI NILAI (TKN) TERHADAP KECERDASAN SOSIAL DAN HASIL BELAJAR SISWA TEMA PERISTIWA DALAM KEHIDUPAN KELAS V SD NEGERI GUGUS LETDA MADE PUTRA KECAMATAN DENPASAR UTARA TAHUN 2019/2020
}

\author{
N.P. Yuniari ${ }^{1}$, I.W. Lasmawan ${ }^{2}$, I.B.P. Arnyana ${ }^{3}$ \\ ${ }^{123}$ Program Studi Pendidikan Dasar \\ Universitas Pendidikan Ganesha \\ Singaraja, Indonesia

\begin{abstract}
e-mail: yuniari@pasca.undiksha.ac.id ${ }^{1}$, wayan.lasmawan@undiksha.ac.id ${ }^{2}$, putu.arnyana@undiksha.ac.id ${ }^{3}$
\end{abstract}

\begin{abstract}
Abstrak
Penelitian ini bertujuan untuk mengetahui pengaruh implementasi teknik klarifikasi nilai (TKN) dalam pembelajaran PKn baik secara simultan dan terpisah terhadap kecerdasan dan hasil belajar peserta didik kelas V sekolah dasar (SD) Gugus Letda Made Putra. Populasi penelitian ini adalah seluruh peserta didik kelas V SD di Gugus Letda Made Putra Denpasar Utara Tahun ajaran 2019/2020 yang terdiri dari 409 siswa. Dari jumlah itu, dipilih 120 siswa dengan teknik sampel acak. Data kecerdasan sosial dikumpulkan dengan kuesioner skala Likert dan data hasil belajar dikumpulkan dengan tes isian singkat. Data yang diperoleh dianalisis secara statistik dengan formula MANAVA pada taraf kesalahan 5\% dengan bantuan SPSS. Hasil analisis menunjukan bahwa 1) terdapat pengaruh signifikan Teknik Klarifikasi Nilai (TKN) terhadap kecerdasan sosial dengan probabilitas sebesar $0,00,2)$ terdapat pengaruh signifikan Teknik Klarifikasi Nilai $(T K N)$ terhadap hasil belajar dengan probabilitas sebesar 0,00 dan 3) terdapat pengaruh signifikan Teknik Klarifikasi Nilai (TKN) terhadap kecerdasan sosial dan hasil belajar secara simultan dengan nilai probabilitas sebesar 0,00. Dari hasil ini dapat disimpulkan bahwa TKN secara simultan dan terpisah berpengaruh terhadap kecerdasan dan hasil belajar siswa. Temuan ini berimplikasi pada penerapan teknik klarifikasi nilai dalam pelajaran PKn sebagai upaya memperbaiki dan meningkatkan kecerdasan sosial dan hasil belajar siswa khususnya pada tema "peristiwa dalam kehidupan'. Saran penelitian ini adalah perlunya evaluasi materi pelajaran PKn yang dapat dibelajarkan dengan teknik klarifikasi nilai dan guru harus demokratis ketika siswa memilih karakter yang disukai.
\end{abstract}

Kata Kunci : Hasil Belajar; Kecerdasan Sosial; TKN

\begin{abstract}
This research aims at knowing the effect of clarification value technique (CVT) on social quotients and result of learning of fifth grade students in Letda Made Putra group North Denpasar SubDistrict. The population of this research was the fifth grade students in Letda Made Putra group in the academic year 2019/2020 consisting of 409 students. Through random sampling, 120 students were selected to be samples. The data of social quotients were collected by using questionnaire with Likert scale data of learning result were collected by short essay test. The collected data were analyzed staitistically by using MANOVA with signifecance level of $5 \%$ by using SPSS. The results of this research are : 1) there is a significant effect of CVT on students' social quotients with probability value of $0.00,2$ ) there is a significant effect of CVT on students' learning result with probability value of 0.00 and 3 ) there is a significant effect of CVT on students' social quotients and learning result simultanously with probability value of 0.00 . From these results, it can be concluded that CVT affects significantly on students' social quotients and learning result simultanously and separately. These results imply on the implementation of CVT in Civics Lesson as a way to improve students' social quotients and learning result. This research suggests that 1 ) there is a need for evaluation of civics
\end{abstract}


materials which can be taught by using CVT and 2) the teachers should be democratic when the students select the persons with their characteristics.

Keywords : Result Of Learning; Social quotients; CVT

\section{PENDAHULUAN}

Salah satu tujuan pendidikan nasional adalah membentuk karakter peserta didik agar berbudi pekerti luhur. Siswa tidak hanya diharapkan mampu memiliki kemampuan akademis yang mumpuni, tetapi juga sikap, etika dan moral yang mampu melengkapi kemampuan akademik. Dengan demikian maka terbuntuklah manusia yang utuh.

Penanaman karakter bangsa juga mendapatkan perhatian khusus pada Kurikulum 2013. Pengembangan karakter siswa ditulis secara tersurat pada kompetensi inti mata pelajaran. Selain itu, mata pelajaran yang memfokuskan pada pendidikan karakter menjadi 3, yaitu: PKn, agama dan budi pekerti. Hal ini merupakan upaya nyata bagaimana pemerintah membangun karakter generasi muda yang berbudi pekerti luhur dan tentu siap bersaing di masa yang akan datang.

$$
\text { Pada hakikat pendidikan }
$$

kewarganegaraan merupakan sebuah metode pendidikan yang bersumber pada nilai nilai Pancasila sebagai kepribadian bangsa demi meningkatkan serta melestarikan keluhuran moral dan perilaku masyarakat yang bersumber pada budaya bangsa yang ada sejak dahulu kala. Dalam Kurikulum 2013, mata pelajaran pendidikan kewarganegaraan (PKn) terintegrasi pada mata pelajaran tematik. Melalui mata pelajaran ini diharapkan generasi Bangsa Indonesia dapat mencerminkan jati dirinya yang terwujud dalam berbagai tingkah laku di dalam kehidupan keseharian masyarakat.

Menurut Depdiknas (2006:49), pendidikan kewarganegaraan memiliki beberapa tujuan sebagai sebuah pembelajaran, yaitu: memiliki pemikiran yang kritis dan kreatif serta rasional dalam menghadapi adanya isu Kewarganegaraan, 2) ikut serta dengan cerdas dan bijak juga bertanggung jawab, dalam bertindak secara sadar dalam setiap kegiatan, baik dalam bermasyarakat dan berbangsa maupun bernegara, 3) maju kearah yang lebih positif dan demokratis demi mewujudkan individu yang berdasar pada nilai-nilai pendidikan karakter yang terdapat di masyarakat supaya dapat hidup rukun dan berdampingan sebagai upaya menjaga NKRI dan 4) memiliki hubungan yang baik dengan bangsa lain dan berpartisipasi dalam menjaga ketertiban dunia secara langsung melalui teknologi informasi di era globalisasi saat ini.

Mata pelajaran PKn diberikan kepada siswa sejak tingkat sekolah dasar. Hakekat PKn di Sekolah Dasar adalah sebagai program pendidikan yang berdasarkan nilai-nilai pancasila untuk mengembangkan dan melestarikan nilai luhur dan moral yang berakar pada budaya bangsa yang diharapkan menjadi jati diri yang diwujudkan dalam bentuk perilaku dalam kehidupan sehari hari. Pelajaran yang dalam pembentukan diri yang beragam dari segi agama, sosial, budaya, bahasa, usia, dan suku bangsa memfokuskan pada pembentukan warga negara yang memahami dan mampu melaksanakan hak-hak dan kewajibannya untuk menjadi warga negara Indonesia yang cerdas, terampil, dan berkarakter seperti yang diamanatkan oleh pancasila dan UUD 1945.

Secara operasional pelajaran PKn disekolah dasar diarahkan pada proses pendidikan yang terpadu utuh,yang juga disebut sebagai bentuk confluent educatin, tuntutan pedagogis ini memerlukan persiapan mental,professionalitas,sosial guru-murid yang kohesif Guru siap memberi contoh dan menjadi contoh sesuai dengan postulat bahwa nilai tidak bisa diajarkan ataupun ditangkap. Untuk itu, pembelajaran $\mathrm{PKn}$ harus lebih diarahkan pada kondisi belajar secara praktis dalam memahami nilai-nilai.

Dalam pelajaran PKn di sekolah dasar yang sesuai dengan Kurikulum 2013, ada bererapa topik yang menjadi fokus pelajaran $\mathrm{PKn}$, satu diantaranya 
adalah kecerdasan sosial. Kecerdasan sosial penting dimiliki siswa mengingat merekahidup di lingkungan masyarakat yang multikultur. Untuk itu, diperlukan kecerdasan untuk memahami semua fenomena yang terjadi di masyarakat agar bisa tetap hidup rukun dan damai dalam kehidupan masyarakat yang multikultur.

Kecerdasan Sosial adalah ukuran kemampuan diri seseorang dalam pergaulan di masyarakat dan kemampuan berinteraksi sosial dengan orang-orang di sekeliling atau sekitarnya (Goleman, 2006). Sementara itu, menurut Prawira (2012) kecerdasan sosial adalah kemampuan individu untuk menghadapi dan mereaksi situasi sosial atau hidup di masyarakat. Kecerdasan sosial bukan emosi seseorang terhadap orang lain, melainkan kemampuan seseorang untuk mengerti kepada orang lain, dapat berbuat sesuatu dengan tuntutan masyarakat.

Dengan demikian dapat disimpulkan bahwa kerdasan sosial adalah kecerdasan sosial adalah kemampuan seseorang dalam memahami dan merespon perasaan dan suasana hati orang lain dalam lingkungan sosialnya dengan demikian akan terjalin komunikasi yang positif dan dapat diterima oleh lingkungannya. Mampu hidup harmonis dalam masyarakat sosial dan diterima di lingkunganya merupakan hal yang harus bisa dilakukan oleh semua manusia. Dengan kecerdasan sosial yang baik yang dimiliki anggota masyarakat maka akan terbentukmasyarakat yang hidup saling menghargai dan menhormati.

Mengacu pada pemaparan tentang kecerdasan sosail dapat disimpulkan bahwa kecerdasan sangat berperan dalam kehidupan siswa. keduanya mengarahkan siswa untuk dapat hidup rukun dan harmonis dengan orang lain dalam lingkungan masyarakat yang multikultur. Kecerdasan sosial dapat memfasilitasi siswa memahami perasaan orang lain dan skipa multikultur dapat menumbuhkan sikap toleransi yang tinggi dalam pergaulan.

Namun pada kenyataannya, kedua hal tersebut masih jauh dari harapan. Berdasarkan hasil pengamatan yang dilakukan pada siswa kelas V di SD N 23
Dauh Puri dan SD N 1 Tonja, masih ditemukan kasus berupa penyimpangan terhadap kecerdasan sosial dan sikap multikultural. Masih ada siswa yang melakukan kekerasan yang menjurus pada bully pada temannya. Perilaku ini masih sering terjadi khususnya dilakukan oleh siswa yang memiliki tubuh besar dan kelompok. selain itu,masih juga ditemui siswa yang melakukankekerasan secara verbal dan hinaan kepada temannya. Di samping itu, ada juga siswa yang membentuk kelompok tertentu yang umunya dari satu daerah/tempat asal. Mereka cenderungkurang akrab dan deskriminatif terhadap teman lain yang dari luar daerahnya dan berbeda secara ekonomi dan suku.

Untuk mengetahui faktor penyebab hal ini terjadi dilakukan pengamatan lebih lanjut khususnya pada pola pengajaran di kelas. Hasil pengamatan menunjukan bahwa pembelajaran didominasi oleh metode ceramah. Di sini siswa hanya menghapal setiap materi PKn tanpa adanya pemahaman yang baik tentang materi tersebut khususnya yang berhubngan dengan nilai. Akibatnya, siswa kurang paham tentang perilaku yang telah mereka perbuat cenderung merugikan orang lain. Jika ini dibiarkan terus maka ke depan keharmonisan dalam masyarakat cenderung sulit terlaksana. Untuk itu,perlu dilakukan usaha inovatif sebagai solusinya.

Akibat penerapan model pembelajaran ceramah ini, hasil belajar siswa juga rendah. Berdasarkan hasil buku siswa, rata-rata nilai ulangan harian I tematik siswa hanya 60,35. Hasil ini jauh lebih rendah daripada KKM yang ditetapkan sebesar 75. Para siswa juga kesulitan menjawab soal-soal yang sifatnya pemahaman atau analisis. Mereka cenderung hanya bisa menjawab soal hapalan.

Melihat urgensi permasalahan yang dipaparkan maka dilakukan eksperimen terhadap teknik pembelajaran klarifikasi nilai (TKN) pada mata pelajaran PKn. Menurut Muhtadi (2007), Teknik klarifikasi nilai merupakan suatu teknik dalam pendidikan nilai sehingga peserta didik dilatih untuk menemukan,memilih, 
menganalisis, membantu siswa dalam memecahkan masalah sertamemutuskan dan mengembil sikapsendiri mengenai nilai-nilai hidup yangingin diperjuangkannya. Klarifikasi nilai menekankan bagaimana sebenarnya seseorang membangun nilai yang menurut anggapannya baik, sehingga pada gilirannya nilai-nilai tersebut akan mewarnai perilakunya dalam menjalankan kehidupan sehari-haridalam lingkungan masyarakat (Andriyani, 2015).

$$
\text { Teknik klarifikasi nilai }
$$
memungkinkan siswa untuk memhami dengan baik nilai-nilai moral yang sedang mereka pelajarai. Hal ini karena siswa terlibat aktif dalam membangun pemahamannya tentang suatu nilai dan bagaimana nilai-nilai tersebut dapat diterapkan dalam masyarakat. Siswa mulai dengan menentukan nilai yang meraka anggap baikyang selanjutnya dibawa dalam konteks atau kasus dalam kehidupan masyarakat. Pada saat itulah siswa belajar memahami layak tidaknya nilai-nilai tersebut mereka pertahankan dan terapkan dalam kehidupan seharihari. Hal inilah yang membentuk pemahaman siswa yang utuh tentang suatu nilai.

Hasil penelitian dari Wiweka, Lasmawan dan Marhaeni (2014) menemukan bahwa baik secara terpisah maupun secara simultan sikap sosial dan hasil belajar PKn antara siswa yang mengikuti pembelajaran TKN melalui bermain peran secara signifikan lebih baik daripada siswa yang mengikuti pembelajaran konvensional. Hal ini dapat terwujud karena teknik klarifikasi nilai (TKN) melalui bermain peran menekankan pentingnya interaksi sosial antar siswa terjadinya kerjasama untuk memecahkan masalah dan komunikasi dalam bermain peran sehingga timbulnya pembelajaran PKn yang menyenangkan dan bermakna.

$$
\text { Jika dihubungkan dengan }
$$

kecerdasan sosial dan hasil belajar maka teknik klarifikasi nilai memfasilitasi siswa memahami nilai-nilai yang ada pada dirinya dan mengkonstruksi pengetahuan. Siswa dapat dengan baik bagaimana seharusnya berbuat dalam masyarakat multikultur dan bagimana bisa hidup harmonis di tengah masyarakat. Dengan demikian, mereka lebih paham dan tertanam pada diri mereka kecerdasan sosail dan sikap multikultur yang baik.

Berdasarkan uraian tersebut, maka dapat dirumuskan beberapa permasalahan sebagai berikut.

1. Apakah terdapat pengaruh Teknik Klarifikasi Nilai (TKN) terhadap kecerdasan sosial siswa?

2. Apakah terdapat pengaruh Teknik Klarifikasi Nilai (TKN) terhadap hasil belajar siswa?

3. Apakah terdapat pengaruh secara simultan Teknik Klarifikasi Nilai (TKN) terhadap kecerdasan sosial dan hasil belajar siswa?

Berdasarkan rumusan masalah penelitian di atas, secara rinci tujuan penelitian ini sebagai berikut.

1. Untuk mengetahui pengaruh Teknik Klarifikasi Nilai (TKN) terhadap kecerdasan sosial siswa.

2. Untuk mengetahui pengaruh Teknik Klarifikasi Nilai (TKN) terhadap hasil belajar siswa.

3. Untuk mengetahui pengaruh secara simultan Teknik Klarifikasi Nilai (TKN) terhadap kecerdasan sosial dan hasil belajar siswa.

\section{METODE}

Penelitian ini adalah penelitian eksperimen yang menggunakan rancangan posttest only control group design. Ini berarti adanya perlakuan yang diberikan dan di akhir perlakuan diadakan tes akhir.

Populasi adalah sejumlah kasus yang memenuhi seperangkat kriteria tertentu yang ditentukan peneliti. Kasuskasus bisa berbentuk peristiwa-peristiwa, manusia, hewan, tumbuh-tumbuhan dan sebagainya (Dantes, 2012). Populasi dalam penelitian ini adalah seluruh peserta didik kelas V SD di Letda Made Putra Kecamatan Denpasar Utara Tahun ajaran 2019/2020 yang terdiri dari 409 siswa. Pengambilan sampel dalam penelitian ini menerapkan teknik sampel acak kelompok karena kelas-kelas sudah terbentuk (Sugiyono, 2010). 
Variabel yang diteliti dalam penelitian ini meliputi variabel bebas (independent variable) dan variabel terikat (dependent variable). Variabel bebas (X) yaitu variabel yang mempengaruhi variabel terikat. Sedangkan variabel terikat (Y) adalah variabel yang dipengaruhi akibat adanya variabel bebas. Dalam penelitian ini variabel bebas adalah teknik pembelajaran (TKN dan konvensional). Sebagai variabel terikat adalah kecerdasan sosial (Y1) dan hasil belajar (Y2).

Data kecerdasan sosial dikumpulkan dengan kuesioner skala Likert dan data hasil belajar dikumpulkan dengan tes uraian singkat. Data yang diperoleh dianalisis secara statistik dengan formula MANOVA pada taraf kesalahan 5\% dengan bantuan SPSS

\section{HASIL DAN PEMBAHASAN}

Berdasarkan pengujian hipotesis diperoleh bahwa 1) terdapat pengaruh signifikan Teknik Klarifikasi Nilai (TKN) terhadap kecerdasan sosial dan hasil belajar secara simultan dengan nilai probabilitas sebesar $0,000,2)$ terdapat pengaruh signifikan Teknik Klarifikasi Nilai (TKN) terhadap kecerdasan sosial dengan probabilitas sebesar 0,000 dan 3) terdapat pengaruh signifikan Teknik Klarifikasi Nilai (TKN) terhadap hasil belajar dengan probabilitas sebesar 0,000 . Niilai rata-rata kecerdasan sosial dan hasil belajar siswa yang diberikan perlakuan Teknik Klarifikasi Nilai lebih tinggi dibandingkan dengan yang diberikan teknik konvensional.Dari hasil ini dapat disimpulkan bahwa TKN secara simultan dan terpisah berpengaruh terhadap kecerdasan dan hasil belajar siswa.

Dalam pelaksanaan pembelajaran TKN, siswa dilibatkan secara aktif. Pada awal pembelajaran, siswa diberikan tujuan pembelajaran agar menjadi fokus. Selanjutnya, guru menyajikan materi pelajaran secara umum, contohnya "peristiwa Rengasdengklok". Siswa kemudian diminta untuk mengeksplorasi lebih mendalam materi pembelajaran dengan mencari tahu jalan peristiwa, situasi, nama-nama tokoh yang terlibat dan perannya masing-masing. Di sinilah siswa harus aktif mencari materi pembelajaran dengan teman kelompoknya. Dengan aktif mencari tahu sendiri tentu siswa akan lebih ingat dan paham. Ini akan membuat hasil belajar siswa menjadi baik.

Tahap selanjutnya adalah memilih karakter atau tokoh sesuai dengan materi. Siswa harus dapat memberikan alasan mengapa memilih tokoh tersebut, kesamaan karakternya dengan siswa sendiri dan mencari tahu nilai-nilai yang terkandung dalam peristiwa tersebut. Pada fase inilah siswa diarahkan berpikir kritis dan produktif. Siswa harus bisa berargumen atau menghasilkan argumen tentang keunggulan karakter atau nilai yang dimiliki oleh tokoh dan dirinya. Ini membuat siswa menyadari eksistensi dirinya. Pada tahap ini guru harus memberikan kebebasan pada siswa untuk memilih tokoh. Tidak boleh ada kesan negatif terhadap pilihan siswa.

Tahap selanjutnya, siswa dengan karakter yang dimiliki berada pada suatu peristiwa. Pada tahap ini siswa diarahkan berpikir reflektif apakah karakter yang dia miliki membawa kebaikan atau tidak bagi orang banyak. Di sinilah siswa akan belajar dan mengerti apakah nilai atau karakternya dapat berguna apa tidak. Kalau berguna tentu akan mereka pertahankan, jika tidak tentu mereka harus memikirkan karakternya dan bisa merubahnya menjadi karakter yang lebih baik. Dari sinilah siswa diarahkan cerdas secara sosial.

Proses pembelajaran TKN seperti yang diuraikan mampu memberikan pengaruh yang positif terhadap hasil belajar dan kecerdasan sosial siswa. Hal ini karena siswa dilibatkan secara aktif dalam proses pembelajaran. Siswa mencari materi pembejaran yang ditugaskan baik secara individu dan kelompok. siswa yang terlibat aktif tentu memiliki pemahaman yang lebih kuat dan mendalam. Selain itu, pemberian siswa memilih karakter secara bebas kemudian membuat refleksi dari karakternya pada satu kondisi tentu akan membuat siswa lebih memahami karakter yang seprti apa yang harus mereka miliki agar berguna dalam kehidupan sehari-hari atau di 
masyarakat. Inilah yang membuat siswa bisa memiliki kecerdasan sosial yang baik.

$\mathrm{Hal}$ ini tentu berbeda dengan pembelajaran konvensional. Pembelajaran lebih menekankan pada transfer pengetahuan. Guru yang lebih banyak aktif mengisi pengetahuan siswa dengan kegiatan ceramah. Hal ini membuat pengetahuan siswa hanya berupa hapalan. Dengan hapalan, siswa tentu akan lebih cepat lupa dan kurang memahami materi pembelajaran. tentunya, hal-hal seperti ini kurang memilikipengaruh yang baik terhadap hasil belajar siswa dan kecerdasan sosial siswa.

Hasil penelitian ini sejalan dengan penelitian yang dilakukan oleh Utami (2017). Hasil penelitian menunjukkan teknik klarifikasi nilai berbantuan foklor dapat membentuk karakter ke-Indonesiaan peserta didik. Dengan folklor, peserta didik dapat belajar tentang nilai-nilai karakter dalam setiap ceritanya. Siswa dapat memahami karakter dan bagaimana mengimplementasikannya. Hasilpenelitian ini juga sejalan dengan penelitian yang dilakukan oleh Wibowo (2017). Hasil penelitian menyimpulkan terdapat perbedaan secara signifikan terhadap karakter siswa yang meliputi tanggung jawab, kemandirian dan empati antara siswa yang diberikan perlakuan TKN dengan teknik konvensional.

Sejalan dengan ini, hasil penelitian Rochani (2017) juga menunjukan pengaruh positif TKN terhadap karakter siswa. Hal ini karena TKN mengedepankan keterbukaan peserta didik dalam memberikan pilihan- pilihan peserta didik serta analsis peserta didik terhadap nilai-nilai dalam masyarakat. Peserta didik dapat lebih memahami dan menyadari pentingnya nilai tersebut dipahami dan dilaksanakan dalam kehidupan sehari-hari. Di sini guru diharapkan berperan dalam pembiasaan aplikasi karakter yang dipelajari dan dapat memberikan motivasi bagi siswa untuk selalu belajar mengembangkan karakternya.

Secara teori, hasil penelitian ini didukung oleh beberapa teori atau pandangan ahli. Sanjaya (2008:283) menyatakan teknik klanfikasi nilai membantu peserta didik dalam mencari dan menentukan suatu nilai yang dianggap benar/ baik dalam menghadapi suatu persoalan melalui proses menganalisis yang sudah ada dan tertanam. Siswa diarahkan untuk memahami suatu karakter yang baik dan berguna bagi kehidupannya sehari-hari. Untuk itu, siswa harus terlibat aktif dalam proses pembelajaran yang umumnya mencari tahu, menganalisis dan menyimpulkan.

Hal senada dinyatakan oleh Adisusilo (2013). Melalui pembelajaran dengan TKN peserta didik dilatih untuk menemukan, memilih, menganalisa memutuskan, mengambil sikap sendiri terhadap nilai-nilai hidup yang ingin diperjuangkannya. Dengan demikian, TKN dapat (1) membantu peserta didik untuk menyadari dan mengidentifikasi nilai-nilai mereka serta nilai-nilai orang lain, (2) membantu peserta didik agar mampu berkomunikasi secara terbuka dan jujur dengan orang lain, berkaitan dengan nilainilai yang dia yakini, dan (3) membantu peserta didik agar mampu menggunakan akal budi dan kesadaran emosional yang dimiliki untuk memahami perasaan, nilainilai dan pola tingkah lakunya sendiri.

Berdasarkan hasil analisis data muncul dua implikasi pada penelitian ini. Pertama, pembelajaran tematik kompetendi dasar PKn khususnya tema "Peristiwa dalam Kehidupan" hendaknya menggunakan Teknik Klarifikasi Nilai. Penelitian ini telah membuktikan bahwa teknik ini memiliki pengaruh yang baik terhadap kecerdasan sosial dan hasil belajar siswa kelas V. Langkah-langkah pembelajaran Teknik Klarifikasi Nilai, mengarahkan siswa berpikir kritis dalam memahami materipelajaran dan bagaimana harus mengembangkan sikap dalam kehidupan sosial. Selain itu, dengan melibatkan siswa secara aktif dalam pembelajaran dan mengenal norma atau karakter seseorang siswa dapat lebih mudah menerapkannya dalam kehidupan.

Kedua, pembelajaran tematik khususnya yang berkaitan dengan PKn dan IPS harus lebih diarahkan pada penemuan jati diri atau nilai-nilai sosial 
pada diri siswa. Hal ini bertujuan untuk membuat siswa lebih menyadari eksistensi dirinya. Dengan siswa diberikan kebebasan memilih tokoh dan karakter tokoh tersebut, siswa akan menjadi lebih baik dalam mengenal karakternya apakah dia setuju atau tida setuju dengan karakter tokoh yang dipilih. Ini akan mengarahkan siswa untuk menjadi cerdas secara sosial dalam pergaulan.

\section{PENUTUP}

Berdasarkan hasi analisis dan pembahasan dapat ditarik tiga simpulan. Pertama, terdapat pengaruh signifikan Teknik Klarifikasi Nilai (TKN) terhadap kecerdasan sosial dengan probabilitas sebesar 0,00 . Nilai rata-rata kecerdasan sosial siswa yang diberikan perlakuan Teknik Klarifikasi Nilai adalah 90,33 yang mana lebih tinggi daripada nilai rata-rata kecerdasan sosial siswa yang diberikan perlakuan teknik konvensional sebesar 80,18. Kedua, terdapat pengaruh signifikan Teknik Klarifikasi Nilai (TKN) terhadap hasil belajar siswa dengan probabilitas sebesar 0,00 . Nilai rata-rata hasil belajar siswa yang diberikan perlakuan Teknik Klarifikasi Nilai adalah 37,05 yang mana lebih tinggi daripada nilai rata-rata hasil belajar siswa yang diberikan perlakuan teknik konvensional sebesar 31,73. Ketiga, terdapat pengaruh signifikan Teknik Klarifikasi Nilai (TKN) terhadap kecerdasan sosial dan hasil belajar secara simultan dengan nilai probabilitas sebesar 0,00 . Nilai rata-rata kecerdasan sosial siswa yang diberikan perlakuan Teknik Klarifikasi Nilai adalah 90,33 yang mana lebih tinggi daripada nilai rata-rata kecerdasan sosial siswa yang diberikan perlakuan teknik konvensional sebesar 80,18. Nilai ratarata hasil belajar siswa yang diberikan perlakuan Teknik Klarifikasi Nilai adalah 37,05 yang mana lebih tinggi daripada nilai rata-rata hasil belajar siswa yang diberikan perlakuan teknik konvensional sebesar 31,73.

Berdasarkan simpulan sebelumnya maka ada saran-saran yang diberikan kepada guru dan peneliti lain. Guru sekolah dasar khususnya kelas V diharapkan melakukan evaluasi terhadap materi pembelajaran Tematik khususnya tema "Peristiwa dalam Kehidupan". Dengan demikian, para guru bisa memutuskan pada materi apa saja teknik klarifikasi nilai dapat diterapkan. Penggunaan teknik pengajaran yang tepat akan mendorong siswa lebih aktif mengkonstruksi pengetahuannya dan berimbas pada perubahan perilaku siswa ke arah yang lebih baik.

Dalam menerapkan TKN, hendaknya guru bersikap demokratis dengan tidak menyatakan jawaban siswa salah. Akan tetapi, guru harus mampu mendorong siswa memahami nilai-nilai moral atau karakter yang lebih baik. Siswa yang merasa nyaman belajar sangat menentukan keberhasilan Teknik Klarifikasi Nilai.

Peneliti lain diharapkan melakukan penelitian lanjutan terhadap pengaruh TKN terhadap aspek karakter yang lain. Sehingga dapat diketahui pengaruh positif teknik ini terhadap nilai-nilai moral tertentu. Selain itu, peneliti lain juga dapat meneliti teknik apa saja yang dapat membawa pengaruh positif terhadap kecerdaan sosial dan hasil belajar tematik siswa di kelas V. Hal ini penting dilakukan agar selama pengajaran tematik di kelas $\mathrm{V}$ di sekolah, guru dapat menerapkan teknik yang bervariasi.

\section{DAFTAR RUJUKAN}

Adisusilo, Sutarjo J.R. 2012. Pembelajaran Nilai- Karakter. Jakarta: PT Rajagrafindo Persada

Bunyamin Maftuh. (2008). Internalisasi Nilai-Nilai Pancasila dan Nasionalisme Melalui Pendidikan Kewarganegaraan. Educationist Vol. 2 No. 2, 60-78.

Depdiknas. 2006. Panduan Penyusunan KTSP. Jakarta: Badan Standar Nasional Pendidikan.

Djahiri, AK. 1992. Strategi Pengajaran Nilai-nilai Moral VCT dan Games dalam VCT. Bandung: Jurusan PMKPKN IKIP Bandung.

Goleman, Daniel. 2015.Social Intelligence. (Alih Bahasa: Hariono S. Imam). Jakarta: Gramedia Pustaka Utama. 
Vol.5 No 1, Pebruari 2021

ISSN: 2613-9553

Peterson,C.2006.A primer in positive psychology. Oxford, England: Oxford University Press.

Zubaidi. 2005. Pendidikan Berbasis Masyarakat.Yogyakarta : Pustaka Pelajar 